\title{
Moodustusviisi ja tähenduse vahekorrast eesti värvinimetustes
}

Vilja Oja

Teesid: Artiklis antakse kokkuvõtlik ülevaade eesti keeles värvust väljendavate keelendite struktuurist ning selle seostest tähendusliku küljega. Värvinoomeneid kasutatakse peamiselt omadussõna funktsioonis mingi objekti värvuse kirjeldamiseks. Vormilt võib eestikeelne värvinimetus olla nii juursõna, sufiksiline tuletis, liitsõna kui ka mitmest sõnast koosnev omaette tähendusega ühend. Eriti rohkesti leidub võrdlusest lähtuvaid liitnimetusi. Eestikeelsete värvinimetuste hulk ei ole lõplik, vaid neid luuakse kõnes pidevalt juurde. Uued nimetused on üldiselt arusaadavad, kui need järgivad keeles olemasolevat süsteemi, kuna moodustusviisil on mitmel juhul tähenduse seisukohast oluline roll.

Märksõnad: eesti keel, murded, paronüümia, võrdlusalus, värvi nimetamismotiivid, värvinimetuste struktuur

\section{Sissejuhatus}

Nagu teada, ei ole värvimõistete jaotus erinevates kultuurides ja eri keeltes ühesugune. Erinevusi leidub aga ka ühe keele piires, kas murdeti, isikuti või kirjeldatavast objektist sõltuvalt. Näiteks vikerkaart on eesti Lutsi murraku keelejuht kujutanud kolmevärvilisena: "Jumala luuk ['look'] um taiva pääl, timä um kolmeh näoh ['kolmevärviline'], sinine, verrev ['punane'] ni vahanõ ['kollane']", üks Sangaste murraku keelejuht piirdus veel suurema üldistusega, öeldes: "Vikakaar üle taiva om siande verrev luuk". Käesolevas artiklis kirjeldatav eesti värvinimetuste süsteem põhineb 20. sajandi jooksul kõneldud eesti kirjakeele ja murrete sõnavara analüüsil. Materjali kogu sisaldab üle 20 tuhande kasutusnäite, erinevaid nimetusi oli üle 1400, sealhulgas 350 erinevat punase nimetust, 252 erinevat halli värvi nimetust jne. Tänapäeva kirjakeelest erinevad tunduvalt mitme värvi üldnimetused ${ }^{2}$ Kagu-Eesti murretes, näiteks verev (verrev, verre) 'punane', haĺjas ([h]aĺlas(s), [h]aĺass) 'roheline', (h)ahk 'hall', vahanõ ( vahass) 'kollane' (häälikkujudest ja levikust täpsemalt vt Oja 2011). 
Tähtsuseta pole asjaolu, et kuni 19. sajandi keskpaigani oli Eestis käibel kaks kirjakeelt - põhjaeesti murdel baseeruv nn Tallinna keel ja lõunaeesti murret järgiv nn Tartu keel.

Et värvinimetusi kasutatakse enamasti mingi objekti inimsilmale tajutava omaduse, värvuse kirjeldamiseks, võib neid käsitleda kui omadussõnu. Teisalt tähistab sama termin vastava värvusega objekti ennast (värvainet, looma jm), täites sel juhul nimisõna funktsiooni. Siinses kirjutises ei ole sõnaliik määrav. Samas on hea meenutada Henn Saari (1993: 96) väidet, et asjade, olendite ja nähtuste nimetused on pelgad substantiivid seni, kuni neid pole oma omaduste pärast adjektiivina lausesse pandud. Substantiivide ja samakujuliste adjektiivide vahelise piiri hajuvust on rõhutanud ka näiteks Valmen Hallap (1984). Alljärgnevalt pööratakse tähelepanu peamiselt eesti värvinimetuste struktuuri ja tähenduse seostele ning tuuakse esile lokaalseid erinevusi. Eestikeelne värvinimetus võib olla juursõna, liitega tuletis, liitsõna, aga ka kahest või enamast sõnast koosnev omaette tähendusega ühend. Sellise jaotuse alusel käsitletakse keeleainest kolme alapeatüki (2.-4.) raames.

\section{Juursõnad}

Juursõnade positsioonis on suhteliselt vähe vanu värvinimetusi. Laiemalt on kasutatud ebaselge päritoluga sõna must, läänemeresoome või koguni soomeugri tüvega ( $h$ ahk ning varast balti laenu hall, mille häälikulised vasted on kuulunud algläänemeresoome perioodi (SKES: 45, 52, 353-354; EEW 251, 272; SSA 1: 124, 133; SSA 2: 183; EES 65-66, 68, 289). Enamik eesti keeles juursõnadena esinevaid värvinimetusi on laensõnad. Üldlevinud on alamsaksa laen pruun (murdes ka ruun, pruum), vrd asks brūn (EEW 2186; EES 436). Nii kirjakeeles kui ka murretes on kodunenud ka saksa keelest laenatud lilla ja roosa < sks lila, rosa (EEW 2537; EES 241, 387). Kirjakeeles omaks võetud uuemaid laene, nagu oranž (< sks orange - EEW 1840), beež (< ?sks beige - EEW 132), kreem (< sks Kreme - EEW 982), purpur (vrd sks Purpur - EEW 2241) jt tarvitati 20. sajandil murretes harva ja mõnda neist pigem liitnimetuse osisena, nt purpurpunane (vrd sks purpurrot) (vt 4.2.2). Tänapäeva eesti keeles kirjeldatakse värvust nii värvaine nimena laenatud sõnadega (näiteks: violett, ooker) kui ka võrdluse alusel mingi värvilise eseme või aine nimetusega (näiteks: bordoo eesriie, türkiis veepind). Tööstuslikult toodetud värve tähistavad võõrsõnad, nagu ooker, violett, kinaver (murdeis tsinoober < sks Zinnober) jt seostusid algselt ainult konkreetse värvainega. Vastava värviga töötlemisel saadud tooni väljendati vajaduse korral liitsõna või ühendiga, milles värvaine nimetus oli täiendosiseks. Rahvakeeles on sageli võõrapäraseid sõnu mugandatud, andes 
neile mingit omakeelset sõna meenutava kuju, olgugi et viimasel pole kirjeldatava värviga midagi ühist. Näiteks kollast värvainet orle(j)an, saksakeelse nimega Orlean(s) (< pr orléans EEW 1845) on eesti murretes nimetatud ordejaan, ordijoon, ordjon, ort jm, violeti (< sks violett - EEW 3870) asemel on murdeis öeldud viiol, viiul, viiulit, viiolatt, viiulett jms. Enamasti on sellistele moodustistele lisatud üldisem värvinimetus, nt viiulipunane (vt 4.2.2).

Omaette rühma moodustavad nimetused, millega iseloomustatakse eelkõige loomade värvust. Nende hulgas on vanemaid ja uuemaid, tundmatu päritoluga sõnu ning selgeid laene. Osa neist kirjeldab peamiselt hobuste värvust, näiteks kõrb (murdes kõrv jt) 'punakaspruun', hiir 'ebaühtlane hall', lepp 'hele punakaspruun', kimmel, raudjas 'tumepruun', tuhk 'hall', võik 'hallikas- või punakaskollane', teisi on kasutatud rohkem seoses veistega (näiteks leet) või märgivad nii hobuste ja veiste kui ka teiste loomade, aga ka muude objektide värvust (näiteks paat või Hiiu murdesõna asu) (täpsemalt vt Oja 2003). Sageli esinevad samad sõnad $u$ - ja $i$-liitelistena (vt tuletised). Selliseid tuletisi on tekstis mõnikord raske juursõnadest eristada, kuna keeles toimunud häälikumuutuste tagajärjel võivad need teatud vormides kokku langeda. Näiteks samatähenduslikud hiir ja hiiru käänduvad ühtmoodi (g hiiru, p hiirut), saarte murde värvinimetuste lepp ja lepu ainsuse vormid erinevad üksnes nimetavas ja osastavas käändes.

Mõned $e$-lõpulised värvinimetused on vormilt nn $e d a$-adjektiivid (läänemeresoome $<*-e \delta a)$. Levinuimate sõnade, valge, ruske 'punakaspruun, pruunikaspunane' ja ruuge '(punakas)kollane, helepruun' tuletusalus eesti keeles iseseisva sõnana ei esine.

\section{Tuletised}

Paljud eesti värvinimetused on moodustatud omadussõnaliidete abil vastavalt eesti keele omadussõnade tuletusmallidele (vt nt EKG 557 jj.) Eesti keele kõige produktiivsem omadussõnaliide on -ne (g -se, murdeis ka -tse, -dse ) (täpsemalt vt Vare 1984: 67 jj; Kasik 2015: 348 jj). Liitel -ne on vasted kõigis läänemeresoome keeltes ning algkujuks on rekonstrueeritud *-(i)nen (Laanest 1975: 135). ne-liide esineb näiteks peamiste spektrivärvide nimetustes, nagu punane (vrd sm punainen), sinine (vrd sm sininen), kollane (murdeis `kolne, `koldne, `koldane, `kõldane, kõllan, `kõldanõ), peamiselt Tartu ja Võru murdes tarvitatav murdesõna vahane, (vahanõ, vaan) 'kollane'. Sama tuletustüüpi järgivad paljud muud värvinimetused nii kirjakeeles kui ka murretes. Tuletusalus märgib sageli hästituntud objekti, mille värviga kirjeldatavat tooni võrreldakse, näiteks roostene 'roostepruun', (Jämaja) linune 'linavalge', metallinimetuste alusel 
moodustatud kuldne (kullane jt), hõbedane (murdeis õbene, hõpene jt), vaskne (murdeis vasinõ g vasi $\mid$ tsõ -dsõ) ${ }^{3}$, uuematest laensõnadest tekkinud tuletised, näiteks purpurne 'purpurpunane', türkiisne, lasuurne jt. Mõned tuletised on moodustatud värvainet märkivate sõnade baasil, näiteks (Kihnu) madaranõ 'madarapunane'. Võru murdes esineb ne-tuletisi rohkem kui mujal ning mõnel juhul on siin -ne (-nõ) lisatud ka tavalisele värvinimetusele, näiteks: roosanõ 'roosa', hahanõ 'hall'. Üksikutes lõunaeesti murde värvinimetustes asendab -ne sufiksit sellega sisuliselt võrdväärne ja muutevormides kattuv -ss, näiteks (Hargla) vahass (= vahanõ) g vaha(d)sõ 'kollane', (Lutsi) tõrvass miis 'tõmmu mees'.

Funktsioonilt on ne-sufiksile väga lähedane -line, osalt nende esinemissfäär isegi kattub (Viires 1963: 274-275). Liitsufiks -li|ne (<*-llinen) koosneb sisuliselt alalütleva käände lõpust ja sufiksist *-(i)nen (nt Laanest 1975: 146). Üldiselt on -line eesti keeles üks enim kasutatavaid omadussõnaliiteid (vt Vare 1984: 46; Kasik 2015: 353 jj). Värvinimetuste hulgas on aga line-tuletisi vähe, üldtuntud on roheline, murretes ka rohiline, roholine jt. Murretes esinevad line-tuletiste asemel või kõrval seaduspäraselt lane-tuletised (vt Viires 1963: 340). Näiteks rohelise värvi nimetus on osaliselt läänemurde, Tartu ja Võru murde alal rohelane või rohilane (Võru -lanõ).

Loomade karvkatte värvust väljendatakse sageli $u$ - ja $i$-liiteliste sõnadega hiiru, leedu, lepu, rebu, tõmmu, tuhi, haŕmi jt. Liidete $-u$ ja $-i$ (<*-oi, -õi) abil moodustatakse üldiselt deminutiivseid noomeneid, sealhulgas loomanimesid (Mägiste 1928). Värvinimetuse tähendust need liited ei muuda, vaid sama tüvega sõnad on omavahel sünonüümid, näiteks lepu $=l e p p$, tuhi $=$ tuhk, harmi = harm jt. On täheldatud, et deminutiivsuse kõrval täidavad $i$-lõpulised diftongid soome-ugri keeltes ka omadussõnaliite funktsiooni, märkides millegagi varustatavust või kokku kuuluvust, mingi tunnuse omamist jms (Rapola 1919-1920: 85; Setälä 1888: 136).

Väga palju värvinimetusi saab moodustada eesti keeles hästi produktiivsete liitsufiksitega -kas g - ka ja -jas g -ja. Need on tekkinud läänemeresoome sufiksist

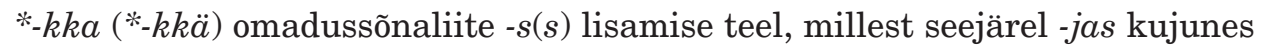
ilmselt sisekao tulemusel (Laanest 1975: 136, 144; Koski 1983: 306). Üldiselt sõltub -kas ning -jas tuletiste tähendus suuresti tuletusaluse sõnaliigist (Vare 1984: 10; EKG: 584-588; Kasik 2015: 361). Omadussõnast lähtunud tuletised väljendavad omaduse vähesust. Nii ka värvinimetusest moodustatud kas- või jas- tuletis märgib harilikult vastava värvuse nõrgemat astet. Kahesilbilistest pikemad sõnad on liite -kas ees lühenenud, näiteks: punakas < punane, kollakas $<$ kollane. Sufiks -kas liitub ainult vokaaltüvele, kuid -jas liitub nii konsonandile kui ka vokaalile, värviadjektiivist tuletusaluse puhul peamiselt ühesilbilisele konsonanttüvele, näiteks valkjas < valge, mustjas < must. Nimisõnalise tule- 
tusaluse puhul on enamasti tegemist välisel sarnasusel põhineva võrdlusega, näiteks: haabjas 'haavakoore värvi hall' < haab, (Sangaste) munakass, muna ‘karva. Tuletusaluseks oleva värvinoomeni tähendust muudavad -kas ja -jas sarnaselt, st samast adjektiivitüvest lähtuvad paralleelsed tuletised on sünonüümid, näiteks: sinakas = sinkjas, savikas = savijass 'savikarva', (Kodavere) tuhakas all = 'tuhkjas aíl 'tuhakarva'. Lõunaeesti murretes esinevad -kane/ -jane (<*-kka+*-inen) liitelised värvinimetused on samatüveliste kas-/ jastuletiste sünonüümid, näiteks kõllakane = kõllakass, Ida-Võru `haabjanõ = haabjas(s), 'muśtjanõ = mustjass jt. Samal alal paralleelselt esinevad -kane ja -kas ning -jane ja -jas (g -dse, -tse) sufiksiga tuletised moodustavad käänamisel sageli segatüübi (vt ka Viires 1963: 402).

Murretest on registreeritud mõned $l i k$-ja $i k$-liitega värvinimetused. Eesti keele omadussõnatuletuses palju kasutatav -lik (g -liku, -ligu) liitub adjektiivitüvele harva ning sel juhul on liide modifitseeriva tähendusega (vt nt Vare 1984: 42; Kasik 2015: 357). Üksikutes murdekeeles leiduvates värvinimetustes toimibki -lik vähendava liitena, näiteks Phl võigulik 'võikjas, hallikas', Lutsi mustalik 'mustjas', 'valgõlik 'valkjas'. Võru murdes esineb lik-sufiksit omadussõnades sagedamini kui mujal. Vähestes omadussõna baasil moodustatud $i k$-tuletistes on samuti täheldatud liite modifitseerivat tähendust (Kasik 2015: 368). ik-liiteliste värviadjektiividega iseloomustatakse sageli loomade karvkatte värvust, näiteks hiirik hopõn 'tumehall hobune', suitsik lammass 'hall lammas'. Sellel põhinevad mitmed loomanimed, nagu Haavik, Mustik, Punik, Tõmmik. Värviadjektiivi positsioonis on kasutatud ka verbi partitsiipe, nagu punerdav, punetav, sinerdav, kullendav, sinav, mustav, murretes tulitanud, kulõhunu jt. Lõunaeestikeelne punase värvi nimetus ver(r)ev on tõenäoliselt samuti tulenenud oleviku partitsiibist (Laanest 1975: 143).

Ainult Võru murdes kasutatakse kene- (kõnõ-) liitelisi värviadjektiive. Kirjakeeles deminutiivsust väljendav liitsufiks -kene on Võru murdes sageli minetanud deminutiivse varjundi (Viires 1963: 421). Nii on värvinimetused hahakõnõ 'hall', iirukõnõ, hiirokõnõ 'pruunikashall', mustakene 'must' jt tähenduselt oma tüvisõna sünonüümid. Samuti võib -kene Võru murdes liituda -kas ja -jas sufiksiga värviadjektiivile, lisamata sõnale omapoolset tähendusnüanssi, näiteks: hallikakene 'hallikas', sinkjakõdsõ 'sinkjad'.

\section{Liitnimetused}

Umbes $80 \%$ kogutud värvinimetustest on liitsõnad või mitmesõnalised ühendid. Suulisest keelest kirja pandud materjali puhul on liitsõna ja mõisteliselt kokku kuuluva mitmest sõnast koosneva ühendi erinevus suhteline, mistõttu 
käsitletakse neid alljärgnevalt koos. Värvust tähistav kahest või enamast sõnast moodustatud ühend koosneb tinglikult kahest poolest: täiend- ja põhiosisest ning kumbki komponent võib omakorda olla nii juursõna, sufiksiline tuletis kui ka mitmesõnaline ühend (kokkuvõtlik süsteem vt Oja 2007: 206-207). Liitsõna muuttüübi määrab eesti keeles teatavasti viimane moodustusosa, põhisõna. Liitvärvinimetuse põhisõna positsioonis on kas muutumatu sõna (parameetersõna või seotud järelosis) või värvinimetus.

\subsection{Põhisõnaks parameetersõna või seotud järelosis}

Eesti keeles (nii kirjakeeles kui murretes) väljendatakse sageli värvust ühendiga, mille järelkomponent ei muutu käändes ega arvus. Selline järelkomponent on parameetersõna värv, karv jt või omaduse määra vähendav seotud järelosis -võitu vms. Niisuguseid omadussõna funktsiooni täitvaid muutumatuid sõnu on nimetatud omadussõnalisteks adverbideks (Kask 1967: 93; Laanest 1959: 214), sekundaarseteks adjektiivideks (Erelt 1979: 3) ja vaegadjektiivideks (EKG I: 16). Sõna karv lisamist nimi- või omadussõnalisele täiendosale peetaksegi läänemeresoome keelte vanaks värvuste nimetamise mooduseks (Laanest 1959: 214; Koski 1983: 326). Tänapäeva eesti keeles käibivad karv sõna kõrval analoogilise parameetersõnana värv ja toon (murretes ka nägu) harilikult osastava, harvem kaasaütleva käände vormis. Samas tähenduses on põhisõnadena käibel samatüvelised ne- või line-liitelised omadussõnad -karvaline, -värviline, -tooniline, (murdeis ka -karvane, -karune, -näoline) ning ning järelosised -poolne, -sugune jt. Henn Saari (1978: 53) soovitas käsitada selliseid liitsõnu, mille põhiosaks on adjektiivisufiksiga tuletis, parameetersõnast, liitsõnatuletistena. Omadussõnatuletisi põhjalikult uurinud Silvi Vare (1984: 107) liigitas sellised sõnad ühendtüvelisteks sufiksadjektiivideks. See sõnade kategooria on tuntud ka teistes läänemeresoome keeltes.

\subsubsection{Omadussõna + parameetersõna}

Omadussõnaline täiendosis (harilikult värvinimetus) ühildub vormilt osastavas käändes parameetersõnaga ning mõlemad komponendid püsivad lauses muutumatul kujul, näiteks pruuni karva, hahkjat karva, halli värvi, kahvatut värvi, roosakat tooni. Kaasaütleva käände vormis parameetersõnale eelneb omastavas käändes värvinimetus, näiteks (Jämaja) pruuni punaka `näuga [muld]. Adjektiivne parameetersõna liitub samuti omastavas käändes värvinimetusele, näiteks pruunikarvaline, hallivärviline, sinisetooniline, tumedatooniline. Värvinimetusest ja parameetersõnast koosneva ühendi tähenduse määrab täiendosis, parameetersõna üksnes kinnitab, et kõne all on värvus. 


\subsubsection{Nimisõna + parameetersõna}

Parameetersõnaga ühendi moodustav nimisõna märgib objekti, millega kirjeldatavat värvust võrreldakse. Võrdlusalust märkiv nimisõna on sel juhul omastavas käändes. Substantiivne parameetersõna on enamasti osastava vormis, näiteks tulekarva, tuhakarva, sinepi värvi, kirsi värvi (vt nt Vare 2012, s.v. karv2). Adjektiivne parameetersõna aga käändub vastavalt lause sisule (näiteks kullakarvaline [õis]; [kandis] kullakarvalisi ehteid; [kauss läks pestes] vasekarvaliseks). Kõnekeeles tarvitatakse ka kaasaütlevas käändes parameetersõna, näiteks (Juuru) tolmukarvaga 'hallikas' veis; (Jämaja) rugilille näuga 'rukkilillesinine'. Mõnest liitsõnast struktuuriga nimisõna + parameetersõna on kujunenud ühe kindla värvi nimetus, ehkki võrdlusaluseks oleva objekti värvus varieerub, näiteks sirelikarva e sirelivärviline 'sirel(i)lilla', taevakarva 'taeva(s)sinine' (EKSS; ÕS). Loodusobjektide värvusega võrdlemisel on oluline pidada silmas lokaalseid erinevusi. Näiteks Lõuna-Eestis märgivad sõnad savikarva (Setu sau karva) kollakat-pruunikat-punakat värvust, aga põhjarannikul (Kuusalu, Lüganuse) iseloomustatakse sõnadega save karva ja save värvi teatud halli värvitooni, mis sarnaneb kohaliku saviga (EMSUKA).

\subsubsection{Värvinimetus + seotud järelosis}

Ühendis värvinimetusega põhisõna positsioonis olevad juhti, vuhti, -võitu, -natu, -poolne, -sugune osutavad peamiselt täiendosises nimetatud värvuse osalisele esinemisele, seega toimivad sarnaselt vähendava sufiksiga -kas / -jas jms. Sõnad juhti ja vuhti liituvad harilikult partitiivi vormis värvinimetusele, näiteks (Lüganuse) 'valget 'vuhti 'valkjas'; (Nõo) sinist `juhti ‘uńdrik 'sinakas seelik'; (Urvaste) verevät 'juhti rõõvass 'punakas riie'. Kui põhisõnaks on seotud järelosised -võitu, -natu, -poolne, -sugune, on täiendosis omastavas käändes, näiteks ruskevõitu 'ruskjas', verevapoolne 'punakas', hahasugune 'hallikas', (Muhu) allinatu 'valkjashall'.

\subsection{Põhisõnaks värvinimetus}

Põhisõnaks olev värvust märkiv sõna moodustab liitvärvinimetusi nii omadussõnalise kui ka nimisõnalise täiendosisega ning mõnede määrsõnadega. Kirjeldatava objekti domineerivat värvust väljendab sellistes ühendites ikka põhisõna, täiendosis aitab värvitooni täpsustada või annab muud täiendavat infot. Põhisõnaks oleva värvinimetuse struktuur ei ole piiratud, selleks võib olla juursõna, tuletis, aga ka liitvärvinimetus. 


\subsubsection{Omadust märkiv sõna + värvinimetus}

Omadussõnaline täiendosis kirjeldab põhisõnaga väljendatud värvuse mingit omadust detailsemalt, eelkõige värvitooni ja heledus-tumedusastet. Värvuse intensiivsust, sära ja muid omadusi on iseloomustatud ka määrsõnalise täiendosise abil. Omadussõnaline täiendosis liitub enamasti nimetavaliselt.

Kõige tavalisem viis väljendada mitme värvuse kooslust ehk segavärvitoone on kahe värvinimetuse ühend $(\mathrm{VN}+\mathrm{VN})$. Kumbki komponent võib väljendada vastava värvi täis- või osalist esinemist. Enim tarvitatakse vähendava liitega täiendosiseid, näiteks rohekassinine, punakaspruun, valkjashall. Harvem on mõlemad osised deminutiivi vormis, nagu rohekaskollakas. Täisvärvi märkiva täiendosisega ühendeid kohtab peamiselt murdekeeles, näiteks lillasinine, (Pärnu-Jaagupi) sinine must 'sinakasmust', (Karksi) sinine aíl 'sinakashall', (Vastseliina) sinineverrev 'lilla', (Nõo) kõllane verrev 'kollakaspunane' jt. Täiendsõna võib liituda ka lühenenud kujul, nt siniroheline. Saaremaal leidub näiteid genitiivsest liitumisest, näiteks (Pöide) `koltse võik, sinise võik, kollase kõŕb, (Jämaja, Karja) siniseaĺl, (Jaani) punaseköŕb o punaka karvaga, (Kihelkonna) kotkas, see on üks suur musta aĺ lind. Ühendi käänamisel esineb murdekeeles komponentide ühildumist arvus ja käändes, näiteks: (Kolga-Jaani) sinakad allid olid kalevi ‘riided; (Karksi) kesvä terädel lää sõkal päält allikasess ruunikasess 'odra teradel läheb kest pealt hallikaks pruunikaks' (EMSUKA). Kahe värvinimetuse ühendi täiendosiseks võib olla ka liitsõna, mis koosneb võrdlusobjekti tähistavast nimisõnast ja parameetersõnast (vt 3.1.2.) ning põhisõnana järgneb sellele teine värvinimetus, näiteks kullakarva kollane, tulekarva punane, sinepi värvi kollane, kirsi värvi punane. Niisuguses ühendis on samuti põhisõna funktsioonis üldisema tähendusega värvinimetus ning võrdlusest lähtuv täiendosis täpsustab värvitooni.

Erinevate heledus- ja tumedusastmete väljendamiseks kasutatakse suhteliselt väikest hulka omadussõnu, mis liituvad värvinimetusele nominatiivselt. Heledat tooni märgivad täiendsõnad hele, kahvatu, kahkjas, hale, valkjas, murdes valss jt, näiteks helesinine, haleroosa, kahvaturoheline, kahkjaspruun, valkjaskollane, murd. valśshallass 'heleroheline' (täpsemalt vt Oja 1996). Tumedaid toone iseloomustavad peamiselt täiendsõnad mustjas, tume, murdeis tüme, tümbjas, tümbjäne, pime jt, näiteks tumesinine, (Setu) tümbjöne haĺass = 'muśtjanõ haĺass 'tumeroheline', (Lutsi) 'tümbeverrev lihm um pümmeverrev, olõ-i valss 'tumepunane lehm on tumepunane, ei ole hele' (täpsemalt vt Oja 1999). Murretes võivad sellised omadussõnad ühilduda järgneva värvinimetusega, näiteks (Vaivara) 'Konnad on 'tungelid 'pruunid; (Jämaja) tumed sinised; (Hargla) õbõ aíl, ‘valgõst aílist 'valkjashallist' 'raaskõsõ tumõmb. Heledust ja 
tumedust märkivad täiendosised erinevad murdeti, näiteks kirjakeeles ja põhjaeesti murretes tuntud omadussõna valvakas asendab kirderannikumurdes 'vaalas ja lõunaeesti murretes valśs, põhjaeesti sõnade tuhm ja tõmmu asemel öeldakse Võru murdes tinnõ (levikukaardid vt Oja 2000a). Väärib tähelepanu, et erinevalt mitmest muust keelest moodustavad eesti keeles heledust ja tumedust märkivad täiendsõnad ühendeid ka musta ja valgega, näiteks tumemust, tumevalge, Rõuge valss`valgõ (vt Oja 2000b).

Intensiivse värvuse kohta öeldakse kõige sagedamini ere või erk, näiteks erepunane, erkroheline. Sobiva omadussõnalise täiendosise lisamisel värvinimetusele saab mitmeid muidki värvi omadusi esile tuua, näiteks ehtmust, sügavpruun, säravkollane, mattkollane, tuhmroheline, külmsinine jt. Omadussõnadega samas funktsioonis kasutatakse täiendosisena rõhu-ja määraadverbe ühendites nagu näiteks pärislilla, vaevu kollakas, (Laiuse) eht sinine jms. Arvestades, et värvitaju mõjutavad ka objektivälised tegurid, näiteks värvikontrast ja heleduskontrast (vt Allik \& Luuk 1980: 50), võib sama värvust erinevail juhtudel iseloomustada isegi vastandlike nimetustega. Näiteks rohttaim, mis sinilillelehega võrreldes on (hele)roheline, võib lehtsalati kõrval näida lausa tumerohelisena.

\subsubsection{Nimisõna + värvinimetus}

Värvinimetusest põhisõnaga ühendite nimisõnalised täiendosised on peamiselt kaht liiki: ühel juhul on tegemist võrdlusalusega, teisel juhul värvaine nimetusega. Võrdlusest lähtunud liitnimetuste hulk on väga suur ja mitmekesine. Tavaliselt valitakse võrdlusaluseks hästi tuntud värvusega objekt. Üldtarvitatavad värvinimetused on näiteks sinepikollane, rukkilillesinine, kirsipunane, roostepruun jt. Samal viisil saab väljendada mistahes värvust, ainus tingimus, et vestluspartnerid mõistaksid täiendosise värvust ühtmoodi. Seetõttu ei ole niisuguste liitnimetuste hulk eesti keeles lõplik, vaid uusi sõnu moodustatakse jätkuvalt. Näiteks sõna laimiroheline hakati kasutama alles möödunud sajandi 90-ndatel aastatel, kui laimid Eestis müügile tulid. Võrdlusel baseeruvate värvinimetuste moodustamisel on kirjakeeles propageeritud nominatiivset liitumisviisi (vt nt Kask 1967: 65-66), teiselt poolt on tõdetud, et värvivarjundit märkiv täiendsõna on omastavas käändes, näiteks vabarnapunane, sidrunikollane, kohvipruun (Valgma \& Remmel 1968: 317). Mõned sõnad on praegu normeeritud kahel kujul, näiteks kirsi- ja kirsspunane, sinepi- ja sinepkollane, sambla- ja sammalroheline (ÕS).

Murdematerjalis ilmneb siin sõltuvalt liitumisviisist märgatav tähenduslik vahe. Genitiivselt liitunud täiendsõna täpsustab värvitooni, näiteks liivakol- 
lane 'liivakarva beežikaskollane', taevasinine 'helesinine', sirelililla 'helelilla sireli värvi', tulepunane 'tule värvi, kollakaspunane'. Nominatiivselt liitunud täiendsõna rõhutab põhisõnaga väljendatud värvuse intensiivsust või augmentatiivsust, näiteks tulipunane riie on erepunane, tulipunane nägu on tavatoonist tublisti punasem (põhjalikumalt vt Oja 1995b). Mõned intensiivistavas funktsioonis täiendosisena sagedasti tarvitatud sõnad on kujunenud eesti keeles üldisemalt augmentatiivsust märkivaks partikliks, näiteks tuli (tuliroheline, tulisoolane, tuliuus), veri (verinoor, verivaene, verivärske, murdes verivihane). Ühendeis põhisõnadega must ja valge liituvad nimisõnalised täiendosised nominatiivselt nii kirjakeeles kui ka murretes, näiteks kriitvalge, luikvalge, lumivalge, sitikmust, tukkmust, süsimust (Tartu ja Võru murdes hüdsimust). Tegelikult iseloomustavadki sellised liitsõnad musta ja valge värvi intensiivsust. Et eesti keeles omastava käände lõpp puudub, ei ole liitumisviis paljudes sõnades määratletav, näiteks pigimust, rebukollane, telliskivipunane jt täiendosise nimetava ja omastava käände vorm on sarnane.

Taimede ja muude koduste vahenditega värvitud lõnga ja kudumite värvust on kirjeldatud liitnimetustega, mille täiendosis märgib värvainet või värvimismeetodit. Näiteks nõest tehtud seguga värvides saadi tulemuseks nõekollane värvus, lepakoortega tuli lepakoorepruun, madarajuurtega värvimine andis madarapunase (Mulgi murdes maranapunane, Võru maranaverev) jne. Sinise värvi jaoks koguti uriini, lasti sellel potis hapneda ja lahustati seal vasevitriol, tulemuseks oli potisinine värv. Kui potisinise värvi nõusse lisati kaselehti, saadi potiroheline värv. Hiljem, tööstuslikult toodetud värve kasutades, püüti tulemust väljendada samal viisil, näiteks murdesõna liinisinine $(<$ aniliin + sinine) 'lillakaspunane'. Kui täiendosiseks on värvaine nimetus, et saa siiski alati kindlalt väita, et kõneleja viitab värvimisprotsessile. Sama sõna võib tähistada nii võrdlusalust kui värvainet, sest värvust võrreldakse ka värvainega, näiteks (Karksi) mea 'värmsi viiulisinist 'violetti'. Teiselt poolt ei pruugi sarnased liitsõnad alati olla täielikud sünonüümid. Näiteks sügiseste kaselehtedega võrreldav kaselehekollane värvus on erksa tooniga (kuldkollane), aga kaselehtedega värvitud lõng on harilikult kahvatukollane.

Vääriskive ja metalle märkivad täiendosised liituvad värvinimetusele harilikult nominatiivselt. Metallinimetustest lähtuvad komponendid sõnades, nagu kuldkollane, hõbehall, vaskpunane, väljendavad sama värvust ka ühendis parameetersõnaga (kullakarva jt) ja -ne liiteliste adjektiividena (kuldne jt) (vt Oja 1995a). Vääriskivid ei olnud eesti maarahvale tuttavad, nende nimetused on eestlasteni jõudnud esmalt arvatavasti mingi võõra värvuse või värvaine nimedes koos põhivärvi märkiva sõnaga. Näiteks malahhiitroheline (malahhiit 
'roheline vasemaak; tehislik heleroheline tekstiilivärv', vrd sks Malachit, pr malachite), rubiinpunane (rubiin, 'punane vääriskivi', vrd sks Rubin, rubinrot 'rubiinpunane', rubinfarbig 'rubiinivärviline', kld rubinus, ld ruber 'punane'), türkiissinine 'ere rohekassinine' (türkiis 'teat poolvääriskivi', vrd sks Türkis $<$ pr turquoise 'sinine v rohekas mineraal'), smaragdroheline 'erk- või tumeroheline' (smaragd 'vääriskivi', vrd sks Smaragd, kr smaragdos) (vt VL). Selliste liitnimetuste tähendust mõistetakse peamiselt põhivärvi tähistava põhisõna järgi, seda enam, et näiteks rubiinide värvus varieerub punasest lillani, türkiise on siniseid, sinakasrohelisi ja rohelisi. Pealegi ei ole vääriskivid ühtlase värviga, vaid sisaldavad mitmesuguseid kihte.

Terve rida rahvakeeles levinud värvinimetusi, mille sisu tundub esmapilgul arusaamatu, põhineb paronüümial - nende nimisõnaline täiendosis on moonutatud kujuga võõrsõna. Näiteks viiulisinine, viiulipunane < viiul 'violett', ordenikollane < orleani kollane (vrd sks Orleans), pordupunane, pordupruun = bordoo(punane) < bordoo 'veinipunane' (vrd sks bordeauxrot [bor'do:-] 'bordoo, veinipunane' < prantsuse vein, valmistatud Bordeaux' ümbruse viinamarjadest, koosenikollane < košenill (= karmiinpunane, 'kollakaspunane värv, mida valmistatakse košenilltäidest saadavast karmiinhappest', vrd sks Koschenille) (EMSUKA, VL).

Kuigi nimisõnalised täiendosised lisatakse selleks, et täpsustada põhisõnaga väljendatava värvuse tooni, ei ole sellised liitsõnad alati üheselt mõistetavad. Värvaine või värvimisviisi alusel moodustatud liitnimetuste puhul peame arvestama, et vastavalt menetlusprotsessile ja värvaine kontsentratsioonile saadakse värvimisel erinevaid tulemusi. Näiteks potisinisega värvitud lõnga on kirjeldatud sõnadega "helesinine, hallikassinine, erksinine, mustjas", lepakoortega võib värvida kollaseks, punakaks, hele- või tumepruuniks. See kajastub ilmekalt ühesuguse täiendosisega erinevais värvinimetustes nagu madarapunane ja madarakollane, koerputkekollane ja koerputkeroheline, ordenikollane ja ordeniverev, viiulisinine ja viiulipunane jt. Värvuse kirjeldus võrdluse abil eeldab, et kommunikatsioonipartnerid tunnevad võrdlusalust ja mõistavad selle värvust ühtmoodi. Paljud võrdluse baasil moodustatud sõnad on kinnistunud mingi konkreetse värvitooni nimetusena, kuigi võrdlusaluse värvus võib suuresti varieeruda, näiteks telliskivipunane 'kollakaspunane', sirelililla 'helelilla', kirsipunane, 'tumepunane' (vrd 4.1.2 sirelikarva jt). 


\section{Kokkuvõte}

Värvinimetuste moodustusviisi ja kasutust jälgides selgus, et põhiliselt kirjeldatakse nendega värvi kui omadust. Vormiliselt võib värvinimetus olla liitsõna või mitmesõnaline ühend, adjektiivisufiksiga desubstantiiv või lihtsalt omadussõna funktsioonis tarvitatud nimisõna. Kõige rohkem tuletisi on moodustatud ne-liite abil, mida kohtame ka liitsufiksites (nt -line). Seevastu eesti keele omadussõnatuletuses üldiselt väga produktiivne line-liide esineb vaid üksikutes värvinimetustes. Paljud värvust märkivad juursõnad on suhteliselt hilised laenud, mis tähenduse poolest sarnanevad doonorsõnadega (nt oranž, kreem, beež jt). Suur osakaal on liitvärvinimetustel, mille koosseisus prevaleerivad samuti omadussõnaliitega tuletised. Liitnimetuste järelosisena esineb ka parameetersõna värvi, karva, karvaga jms või omadussõnaliitega tuletis värviline, karvaline jt. Parameetersõna variandi ega vormi erinevus liitvärvinimetuse tähendust ei mõjuta, näiteks kullakarva = kullakarvaline $=$ kullakarvane = kullakarvaga $=$ kullavärvi = kullanäoline. Näitamaks värvi osalist taset nimetatud koosluses lisatakse sõnale kas deminutiivsufiks või vähendava tähendusega seotud järelosis (-võitu, -poolne jt).

Värvuste nimetamismotiivid seostuvad põhiliselt kas mingi värvilise objektiga, millega kirjeldatavat värvi võrreldakse, või ainega, mida värvimisel kasutatakse. Võrdlusaluseks saab valida mistahes objekti, tähtis on, et kommunikatsioonipartnerid mõistaksid selle värvust ühtmoodi. Liitnimetustes on värvivarjundit märkiv täiendsõna üldiselt omastavas käändes (nt tulepunane, tulekarva), aga nimetavaline täiendsõna rõhutab sageli intensiivsust (nt tulipunane). Seotud järelosisega ja parameetersõnast põhisõnaga liitvärvinimetustes kannab kvalitatiivset informatsiooni värvuse kohta täiendosis, muudes ühendites põhisõnaks olev värvinimetus. Värvimise tulemus ei sõltu ainult värvainest, vaid ka selle kontsentratsioonist ja värvimismenetlusest. Sama nimetusega värvus varieerub heleduse-tumeduse ja kirkuse osas ning sageli ka värvitooni poolest.

Eesti keel pakub sama värvuse väljendamiseks mitmeid võimalusi. Segavärvitoone kirjeldades toimivad sünonüümidena täpsustavate tuletiste ja liitsõnade kõrval põhivärve märkivad üldnimetused, kusjuures üht värvust on kirjeldatud eri hüperonüümidega. Näiteks pruunikas- või kollakaspunast värvust on nimetatud punane, pruun, kollane ja oranž. Eesti värvinimetuste arv pole piiratud, need kuuluvad nii-öelda avatud süsteemi. Uued sõnad, mis on loodud olemasolevaid moodustusmalle järgides, on harilikult mõistetavad ka esmakordsel kuulmisel. 


\section{Kommentaarid}

1 Eesti murdesõnavara kogust (EMSUKA) võetud näited, mis on varustatud murraku või murde nimetusega, esitatakse Eesti murrete sõnaraamatus kasutatavas transkriptsioonis (http://www.eki.ee/dict/ems/ems.html). Üldistatud sõnakujud on kirjakeelepärases vormis.

2 Üldnimetustena peetakse silmas antud alal kõige üldisemas tähenduses enim kasutatud sõnu, mitte Brent Berlini ja Paul Kay universaalsusteooria kohaselt kindlas järjestuses keeles tekkinud põhivärvinimesid (vt Berlin \& Kay 1969). Eesti keele põhivärvinimesid on uurinud Urmas Sutrop (1995). Siinses artiklis seda teemat ei käsitleta.

3 Metallinimetustest värvuse märkimisel põhjalikumalt vt Oja 1995a.

\section{Sõnavarakogu}

EMSUKA = Eesti murrete ja soome-ugri keelte arhiiv (Eesti Keele Instituut, Tallinn).

\section{Kirjandus}

Allik, Jüri \& Luuk, Aavo 1980. Nägemispsühholoogia. Tallinn: Valgus.

Berlin, Brent \& Kay, Paul 1969. Basic Color Terms. Their Universality and Evolution. Berkeley \& Los Angeles: University of California Press.

EES = Metsmägi, Iris \& Sedrik, Meeli \& Soosaar, Sven-Erik 2012. Eesti etümoloogiasõnaraamat. Eesti Keele Instituut. Tallinn: Eesti Keele Sihtasutus (/http:// www.eki.ee/dict/ety/ - 20. juuli 2016).

Eesti murrete sõnaraamat 1994. I, A-J. Eesti Teaduste Akadeemia Eesti Keele Instituut. Tallinn: Eesti Keele Instituut.

EEW = Julius Mägiste 1982-1983. Estnisches etymologisches Wörterbuch . Helsinki: Finnisch-Ugrische Gesellschaft.

EKG $=$ Erelt, Mati \& Kasik, Reet \& Metslang, Helle \& Rajandi, Henno \& Ross, Kristiina \& Saari, Henn \& Tael, Kaja \& Vare, Silvi 1995. Eesti keele grammatika I. Morfoloogia. Sõnamoodustus. Tallinn: Eesti Teaduste Akadeemia Eesti Keele Instituut.

EKSS = Langemets, Margit \& Tiits, Mai \& Valdre, Tiia \& Veskis, Leidi \& Viks, Ülle \& Voll, Piret (toim) 2009. Eesti keele seletav sõnaraamat. "Eesti kirjakeele seletussõnaraamatu" 2., täiendatud ja parandatud trükk. Eesti Keele Instituut. Tallinn: Eesti Keele Sihtasutus (http://www.eki.ee/dict/ekss/ - 20. juuli 2016).

Erelt, Mati 1979. Predikatiivne adjektiiv (lausemallid). (Eesti NSV Teaduste Akadeemia Keele ja Kirjanduse Instituut.) Tallinn: Rahva Raamat.

Hallap, Valmen 1984. Sõnaliikide piirimailt. Keel ja Kirjandus (1), lk 30-40.

Kasik, Reet 2015. Sõnamoodustus. Eesti keele varamu I. Tartu: Tartu Ülikool. 
Kask, Arnold 1967. Liitsõnad ja sõnade liitumisviisid. Eesti keele grammatika III, 1. vihik. Tartu: Tartu Riiklik Ülikool.

Koski, Mauno 1983. Värien nimitykset suomessa ja lähisukukielissä. Suomalaisen Kirjallisuuden Seuran toimituksia 391. Helsinki: Suomalaisen Kirjallisuuden Seura.

Laanest, Arvo 1959. Partitiivi abil väljendatud substantiivsest atribuudist läänemeresoome keeltes. Emakeele Seltsi aastaraamat IV. Tallinn: Eesti NSV Teaduste Akadeemia, lk 214-232.

Laanest, Arvo 1975. Sissejuhatus läänemeresoome keeltesse. Eesti NSV Teaduste Akadeemia Keele ja Kirjanduse Instituut. Tallinn: Eesti NSV Teaduste Akadeemia.

Mägiste, Julius 1928. oi-, ei- deminutiivid läänemeresoome keelis. Läänemeresoome nominaaltuletus I. Acta et Commentationes Universitatis Tartuensis (Dorpatensis), $\mathrm{XII}_{2}$. Tartu.

Oja, Vilja 1995a. Gold, silver and copper in the Estonian colour names. Linguistica Uralica XXXI (3), lk 178-187.

Oja, Vilja 1995b. Võrdlusel baseeruvaist värviliitsõnadest. Keel ja Kirjandus 12, lk 809_ 817.

Oja, Vilja 1996. Compound adjectives used in the Estonian dialects to denote light and pale shades of colour. Linguistica Uralica XXXII (2), lk 92-100.

Oja, Vilja 1999. Estonian adjectives denoting the darkness of colours. Linguistica Uralica XXXV (3), lk 193-204.

Oja, Vilja 2000a. Murdekaardid mõistetest 'hele' ja 'tume'. Oja, Vilja \& Suhonen, Seppo (toim). Studia ad geographiam linguarum pertinentia. Eesti Keele Instituudi toimetised 6. Tallinn: Eesti Keele Sihtasutus, lk 102-114.

Oja, Vilja 2000b. Tumemust ja helevalge. Viikberg, Jüri (koost, toim). Inter dialectos nominaque. Pühendusteos Mari Mustale 11. novembril 2000. Eesti Keele Instituudi toimetised 7. Tallinn: Eesti Keele Sihtasutus, lk 251-256.

Oja, Vilja 2003. Hobu oli võik, lehm oli leet. Keel ja Kirjandus 2, lk 101-107.

Oja, Vilja 2007. Colour naming in Estonian and cognate languages. MacLaury, Robert E. \& Paramei, Galina V. \& Dedrick, Don (toim). Anthropology of Color. Interdisciplinary multilevel modeling. Amsterdam, Philadelphia: John Benjamins, lk 189-209.

Oja, Vilja 2011. Põhivärvinimetuste vasted eesti murretes. Uusküla, Mari \& Sutrop, Urmas (toim). Värvinimede raamat. Töid antropoloogilise ja etnolingvistika vallast 5. (Eesti Keele Instituut, Tartu Ülikool.) Tallinn: Eesti Keele Sihtasutus, lk 121-140.

Rapola, Martti 1919-1920. Kantasuomalaiset pääpainottomain tavujen i-loppuiset diftongit suomen murteissa (Suomi IV, 17). Helsinki: Suomalaisen Kirjallisuuden Seura.

Saari, Henn 1978. Sünkroonia, diakroonia ja kolm liiki uut keelevara. Rätsep, Huno (toim). Eesti keele grammatika küsimusi. Keel ja struktuur 10. Tartu, lk 42-65.

Saari, Henn 1993. Substantiiv adjektiivina. Keel ja Kirjandus 2, lk 87-97.

Setälä, Emil Nestor 1888. Ueber die bildungselemente des finnischen suffixes -ise (-inen). Suomalais-ugrilaisen Seuran Aikakauskirja III 136, lk 133-138. 
SKES = Itkonen, Erkki \& Toivonen, Yrjö H. \& Joki, Aulis J. \& Cronstedt, Marita \& Tanner, Satu (koost) 1955-1981. Suomen kielen etymologinen sanakirja. Lexica Societatis Fenno-Ugricae, XII; Tutkimuslaitos “Suomen Suvun" julkaisuja, III. Helsinki: Suomalais-ugrilainen seura.

SSA = Itkonen, Erkki \& Kulonen, Ulla-Maija (peatoim) 1992-2000. Suomen sanojen alkuperä: Etymologinen sanakirja 1-3. Suomalaisen Kirjallisuuden Seuran toimituksia 556. Kotimaisten kielten tutkimuskeskuksen julkaisuja 62. Helsinki: Suomalaisen Kirjallisuuden Seura, Kotimaisten kielten tutkimuskeskus.

Sutrop, Urmas 1995. Eesti keele põhivärvinimed. Keel ja Kirjandus 12, lk 797-808.

Valgma, Johannes \& Remmel, Nikolai 1968. Eesti keele grammatika. Käsiraamat. Tallinn: Valgus.

Vare, Silvi 1984. Omadussõnaliited tänapäeva eesti kirjakeeles. Eesti NSV Teaduste Akadeemia Keele ja Kirjanduse Instituut. Tallinn: Valgus.

Vare, Silvi 2012. Eesti keele sõnapered. Tänapäeva eesti keele struktuurianalü̈̈s I, II. Tallinn: Eesti keele Sihtasutus (http://www.eki.ee/dict/sp/ - 20. juuli 2016).

Viires, Helmi 1963. ne-sufiksilised omadussõnad eesti murretes. Dissertatsioon filoloogiakandidaadi teadusliku kraadi taotlemiseks. Eesti NSV Teaduste Akadeemia Keele ja Kirjanduse Instituut. Tallinn (Käsikiri.)

VL = Kleis, Richard \& Silvet, Johannes \& Vääri, Eduard 2012. Võõrsõnade leksikon. 8. täiendatud trükk. Eesti Keele Instituut. Tallinn: Valgus (http://www.eki.ee/dict/vsl/ 20. juuli 2016).

ÕS = Erelt, Tiiu \& Leemets, Tiina \& Mäearu, Sirje \& Raadik, Maire 2013. Eesti oigekeelsussõnaraamat. Eesti Keele Instituut. Tallinn: Eesti Keele Sihtasutus (http:// www.eki.ee/dict/qs/indx.cgi. - 20. juuli 2016).

\section{Summary}

\section{Estonian colour names: Relations between structure and meaning}

Vilja Oja

Keywords: base of comparison, dialect speech, Estonian, naming motives of colour, paronymy, structure of colour names

Estonian words for colours are often produced by adding an adjectival suffix to a noun stem. The most productive adjectival suffix -ne does not change the meaning of the word. The meaning of adjectives with the suffixes -kas and -jas, which occur frequently among colour names, depends on the part of speech of the derivation base. Denominal adjectives describe the colour on the basis of its similarity to an object (e.g. savikas 'clay-coloured' $<\mathrm{N}$ savi 'clay'). If the suffix -kas or -jas (in Võru dialect -kane or -jane) has been attached 
to an adjective, the terms express partial hue content in a colour (e.g. hallikas 'greyish' <Adj. hall 'grey'. Some moderating colour terms are derivatives with an $i k$ - or lik-suffix.

Compounds and phrasal units make up nearly $80 \%$ of all Estonian colour terms. A term consisting of two or more words can conditionally be divided into two parts: the final component is the base word, while the initial one carries the attributive function. Either component may, in turn, be a root word, a suffixed derivative, or a compound or phrase. Colours are often described by phrases in which the final component is not inflected either in case or in number. This may be either (1) a parameter word meaning 'coloured' (e.g. värvi, karva) or an adjectival derivative from the stem (värviline, karvaline, etc.); or (2) a moderating adverb or adjective (e.g. -võitu, -sugune, -poolne).

A large number of Estonian colour names are motivated by the comparison with the colour of a well-known object. A closer look at such phrasal terms revealed that the combination of a part of speech and the way of compounding has a semantic function. Many colour names have their origin in a colouring substance. Borrowed foreign terms are often adapted to fit the Estonian phonetic and lexical system, and sometimes have an absolutely strange word stem (e.g. Gm Orleans > Est ordijoon, ort, etc.). Colour naming represents an open system in Estonian and everybody can find creative ways to describe colours. A new colour name is adequately understandable if it fits into the traditional system used to denote colours in Estonian. 